\title{
Archipel
}

ARCHIPEL Études interdisciplinaires sur le monde insulindien

$93 \mid 2017$

Varia

\section{A rediscovered 1696 decree poster of the Governor General in Batavia, with unexpected stylistic particularities}

Redécouverte: un décret-poster du gouverneur-général à Batavia avec des particularités stylistiques inattendues

\section{Waruno Mahdi}

\section{OpenEdition}

Journals

Édition électronique

URL : http://journals.openedition.org/archipel/402

DOI : 10.4000/archipel.402

ISSN : 2104-3655

Éditeur

Association Archipel

Édition imprimée

Date de publication : 6 juin 2017

Pagination : 85-108

ISBN : 978-2-910513-74-0

ISSN : 0044-8613

\section{Référence électronique}

Waruno Mahdi, «A rediscovered 1696 decree poster of the Governor General in Batavia, with unexpected stylistic particularities », Archipel [En ligne], 93 | 2017, mis en ligne le 01 juin 2017, consulté le 30 avril 2019. URL : http://journals.openedition.org/archipel/402 ; DOI : 10.4000/ archipel.402 


\section{A rediscovered 1696 decree poster of the Governor General in Batavia, with unexpected stylistic particularities**}

\section{Introduction}

It is surely no news to anyone that history is not a singular thread or chain of individual happenings, but a multi-dimensional complex of multifarious interwoven processes, presenting itself to the student in countless facets. Consequently, any single historiographical document may prove to be of significance in numerous aspects.

While choosing perceptible demonstration material for a lecture in Berlin in March 2012, Edwin Wieringa of the University of Cologne, assisted by Thoralf Hanstein of the Berlin State Library, made a remarkable discovery in that library's collection: a rolled $52^{\prime} 73.5 \mathrm{~cm}$ poster with four text columnsca. 23, 16.7, 16.4 and $15.4 \mathrm{~cm}$ wide — in Dutch, Malay, Javanese, and Chinese respectively. Obtaining a scan of the poster roll from the library ${ }^{1}$ for a closer study, I found it to open unexpected insights into aspects of VOC colonial governance.

The Dutch text, dated July 24, 1696, represents a decree of the governor general in Batavia, Willem van Outhoorn. ${ }^{2}$ It is quite unique, because in the

\footnotetext{
*. Fritz Haber Institute of the Max Planck Society

**. This is a completely revised version of an unpublished paper of 2013.

1. The original is too large to reproduce here in facsimile, but an electronic scan is accessible on the Internet at: http://resolver.staatsbibliothek-berlin.de/SBB000083E600000000
}

2. See Appendix 1, I will refer to it as van Outhoorn (1696). An English translation is given in Appendix 2. 
Netherlands-Indies Placard Book (van der Chijs 1885-1900) that provides a documentation of such official documents, comparable texts were only published in abridged and often reedited form. The inspection of stylistic and orthographic particularities of the presently reviewed unabridged and not reedited original can therefore be expected to provide new social anthropological insights into the Indies-Dutch community of VOC employees and functionaries.

Governor General Willem van Outhoorn (*1635 Larike, Ambon; †1720, Batavia) was the son of a Dutch community chief in Maluku. When his father, meanwhile governor of Banda, died in 1653, he was studying law in Leiden, the Netherlands. Returning to the Archipelago in 1659, he successfully climbed the career ladder, and was appointed governor general in $1691 .{ }^{3} \mathrm{He}$ was thus the first Indonesian-born VOC governor general, which provides a further interesting aspect to the subject of this discussion.

His decree, having the form of a public announcement, forbids the opening of new sugar mills, arrack distilleries, chalk burners, brick and tile kilns, and lumber mills in Batavia and environs for reason of scarcity of firewood. Ironically enough, this seems to have been completely ignored, making an inspection of the circumstances around the decree's issuance interesting too.

\section{Original Placard versus Official Posters; Translation Orders}

The presently discovered poster roll is not the original placard of van Outhoorn's decree that is recorded in the Placard Book under the date of June 26 (van der Chijs 1885-1900: 3.405-407), twenty-eight days earlier than the date of the poster. For sake of convenience I write placard for the original document, and practically synonymous poster for a publicly displayed copy of it (a so-called publicatie, literally "publication"), also when one such a poster was subsequently archived besides the original placard. I was unable to acquire a copy of the original placard of van Outhoorn's decree from the Arsip Nasional Republik Indonesia and can only quote it from the strongly abridged record given in the Placard Book.

The last paragraph in the recorded placard, as well as in the Dutch text of the discovered poster, contains the order that local officials display the decree in Dutch, Malay, Javanese, and Chinese on posters in their respective areas of jurisdiction. ${ }^{4}$ Such locally displayed posters were not generally archived. ${ }^{5}$ But the presently considered roll is not some arbitrary poster. Besides bearing

3. Valentyn (1726: 324); Encyclopædie (1917-1921: 3.216); Molhuysen et al. (1924: 1087-9); Stapel (1939: 446); van Putten (2002: 104).

4. With the exception of some short excerpts, I will not touch upon the Malay, Javanese, and Chinese texts. These are abridged translations of the Dutch text. Exhibiting unconventional orthographic particularities, they require individual studies for a complete inspection.

5. A catalogue of the archive that served as source for the Placard Book is provided in Balk et al. (2007: 243-245). 


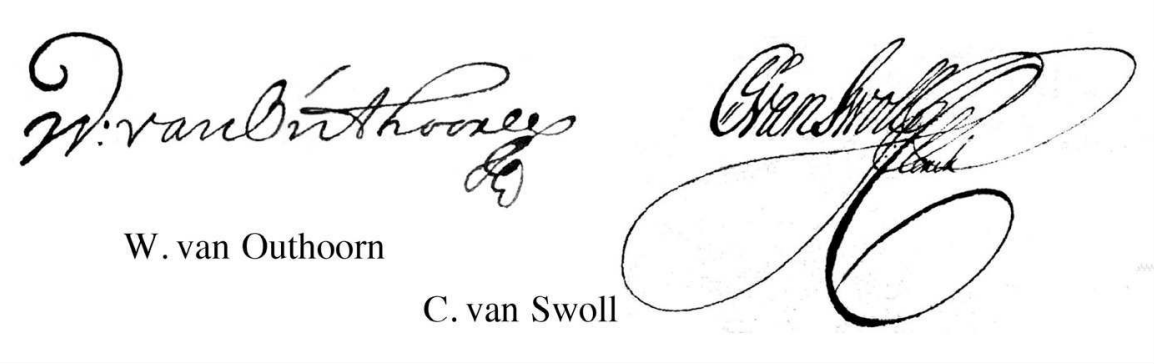

Fig. 1 - Signatures of W. van Outhoorn and C. van Swoll in the van Outhoorn (1696) poster.

Governor General Willem van Outhoorn's signature is countersigned by a C. van Swoll, noted in a subscript to be of the rank of a clerk (Clerck).

This is apparently Christoffel van Swoll (*1663, Amsterdam; $\uparrow 1718$, Batavia), who was appointed secretary of the high government in $1696 .^{6}$ His signature implies that the poster was displayed at the office of the high government, making it a government document as well. The simple signature of the higher ranking van Outhoorn, compared with the ostentatious one of van Swoll with its extravagant swirls, see Fig. 1, suggests that the former was inserted per procurationem by the copyist.

Indeed, many entries in the Placard Book carry two dates: that when the decree was laid down, and that of its public display (van der Chijs 1885-1900: 1.viii). Hence, the notation of two dates indicates that an original placard as well as the poster displayed at the office of the high government had been archived. In our example, only one date is given in the Placard Book, the earlier one, meaning that the placard was archived, but not the official poster. For decrees of Governor General van Outhoorn, for which the Placard Book does provide two dates - twenty-three in all - the difference in date ranges from one to seventy-two days. In three examples it is between twenty-five and twenty-nine days, so that the delay of twenty-eight days of the presently inspected poster roll is not unusual.

The explicit provision to provide the posters with translations seems to have been unique for decrees of that time. Only some decades later, since the 1740s, are Malay translations explicitly noted in the archives. The earliest set that included placards with Malay translations is dated from February 27, 1744, till December 19, 1748 (Balk et al. 2007: 244 no. 2283). It is possible, however, that translations were provided in not-archived posters displayed in areas with a mostly Non-Dutch-speaking population.

6. Encyclopædie (1917-1921: 4.228-229); Molhuysen et al. (1927: 1195-1197), but in 1695 according to Valentyn (1726: 373) who spells his name van Zwol. 
Also for the period, for which Malay translations are noted in the archives, specific orders for such translations are not noted in the Placard Book (van der Chijs 1885-1900: 5.136-542). However, as the placards are not quoted in full, while several explicitly address Chinese, or Malays and other indigenes, some such orders possibly were not noted in the Placard Book.

However, for some decrees with relevance for Chinese persons, an explicit order to include translations is recorded in the Placard Book. The earliest instance - besides van Outhoorn (1696) - seems to have been Governor General Adriaan Valckenier's "Act of amnesty for Chinese" of October 22, 1740 (van der Chijs 1885-1900: 4.513), which provided:

... opdat een iegelyk van dese onse intentie g'informeert moge werden, gelasten wy dese, sowel inde Nederduytse als de inlandse talen, alomme te publiceeren en affigeeren.

... so that everyone be informed about this our intention, we order that this be made public and be displayed in all places in the Dutch as well as indigenous languages.

The next instance was in a decree by Governor General Gustaaf Willem van Imhoff forbidding Chinese persons to offer New-Year presents to employees of the Company, dated December 3 and 12, 1743 (van der Chijs 1885-1900: 5.114):

En, opdat niemand hier van ignorantie soude kunnen pretendeeren, soo lasten en beveelen wy dese, in de Maleydsche en Chineese tale overgeset zynde, alomme te affigeeren.

And, so that nobody should pretend ignorance about this, we order and command that this, translated in the Malay and Chinese languages, be displayed in all places.

Although not explicitly stated in van Outhoorn (1696), it may be assumed that it too was addressed in particular to Chinese entrepreneurs, because these were the principal producers of sugar, arrack, etc. Indeed, the above-cited 1740 and 1741 decrees suggest that illegal business activity of VOC employees were enhanced by contacts with Chinese merchants and moneylenders (compare Ong 1943: 60-61).

\section{The Decree's Historical Context}

The production of sugar, arrack, and the other items indicated in the decree indeed required a steady supply of firewood which was stored since very early at some few specially reserved places (de Haan 1935: 189). A particular role was played by Cornelis Senèn, a Bandanese-born schoolmaster (meester) and church preacher (Brumund 1864: 84), who began providing wood from five square kilometers of forest confined between the Cipinang and Ciliwung rivers. The area would come to be named after him as Meester Cornelis. ${ }^{7}$

By the mid 1690s, the timber reserves in Meester Cornelis were depleted,

7. De Haan (1910-1912: 1.7-8, 2.13 fn. 1; 1935: 329); Encyclopædie (1917-1921: 2.694). It is presently the Jakartan residential area of Jatinegara. 
and this was apparently the reason for van Outhoorn's decree of 1696. Nevertheless, in complete disregard of it, the number of sugar mills simply continued to increase, reaching a maximum of 130 in 1710 (Hooyman 1781: 238). This even proceeded with complicity of the administration: a tripartite contract between the government, indigenous landowning nobility and Chinese entrepreneurs for a new sugar production enterprise was signed in 1707 in Cirebon (Cheribon). ${ }^{8}$ The number of arrack production sites increased even longer: twelve distilleries were reported for 1712, eighteen for 1715 , seventeen for 1752, and twenty for 1761 (Hooyman 1781: 177-178; de Haan 1935: 328).

Consequently, shortage of firewood remained a problem throughout the eighteenth century (see Jacobi 1784). This led at first to relocation of sugar mills ever further from the city, and later also to a forced decrease in their number to eighty in 1738, and sixty-six in 1750 (de Haan 1935: 323-324). Van Outhoorn's decree of 1696 was thus motivated by an objective problem, and its neglect by both the public and administration all the more surprising, raising questions about its political background.

The VOC was a revolutionary trailblazer of corporate enterprise. Sailings around Africa to the sources of coveted spices required such an enormous amount of capital, as could only be provided through collaboration of all the involved previously competing companies as one corporation, an effective mode of enterprise till our days. ${ }^{9}$ However, the period of gradual but steady areal growth and power consolidation of VOC governance and entrepreneurial success in the Archipelago up to the late seventeenth century (see Stapel 1939: 42-422 and Gaastra 2002: 55-61) was followed by a time of internal controversies. Van Leur (1955: 266-267, 270-271) refers to this as a 17th versus 18th century "up-and-down," already happened during the last two decades of the 17 th century.

It began with the governor-generalship of Cornelis Speelman (from 1681 till 1684) who had caused considerable losses for the Company (Stapel 1939: 425-426). To avoid internal disunity through competition, VOC employees had been strictly forbidden to engage in private business. However, temptation and opportunity prevailed, leading to formation of adverse interest groups, undermining the government's structural stability (Day 1904: 101-105). As successor of Cornelis Speelman, the government council surprisingly elected the uninfluential Joannes Camphuys (governed from 1684 till 1691). Many

8. Day (1904: 69). The text of the contract is reproduced in de Jonge (1875: 324-327).

9. See Boxer (1965: 23-24); Steins Bisschop \& Wiersma (2002: 37); Mahdi (2007: 22). This already applied to its immediate precursors, the Vereenigde Zeeuwse Compagnie (in Middelburg) and Eerste Verenigde Compagnie op Oost-Indië tot Amsterdam, established two years before their fusion as VOC (Gaastra 1991: 20; Nagel 2007: 102). The same, of course, also applied to England's East India Company (Baladouni 1983: 63; Robins 2006: 5).

10. See also Boxer (1965: 268ff.). 
had reportedly voted for him by default, to avoid giving their secret vote to a competitor, ${ }^{11}$ revealing the extent of internal disunity.

Camphuys was succeeded in 1691 by van Outhoorn who was allegedly not effective in dealing with corruption (Rijnenberg 1867: 80), but had own interests that led to political controversies (see van Putten 2002: 105106), undermining his administrative authority. He finally resigned in 1701 (Rijnenberg 1867: 80; Encyclopædie 1917-1921: 3.216), but had to remain in office till 1704, because only then could his son-in-law, Joan van Hoorn (*1653, Amsterdam; †1711, Amsterdam)—whom he had managed to get appointed as his successor-finally take office. Above-cited Christoffel van Swoll had directed serious accusations of nepotism against van Outhoorn and van Hoorn (Molhuysen et al. 1924: 804-806; van Putten 2002: 105-106), revealing his enmity. Van Swoll was indeed noted for acting strictly against private business interests. ${ }^{12}$ Whether, however, his enmity towards van Outhoorn may explain why the official poster of the latter's decree was not archived, but got sidetracked, to finally end up in a Berlin library, remains a speculation.

\section{Language and Stylistic Particularities of the Dutch Text}

Particularities of the language of the decree are of interest not only from a purely linguistic perspective. The presently reviewed poster is a relatively unique, genuine, and complete original of a $c a$. 1340-word late seventeenthcentury document written by VOC officials in the colony. It represents a remarkable corpus of contemporaneous Indies-Dutch official style, which allows certain insights into social aspects of the community of Dutch VOC employees.

As noted above, Willem van Outhoorn was Indonesian born. The first language learned by Dutch children born in the colony typically was not Dutch, but the Malay vernacular of their nannies. ${ }^{13}$ However, the Dutch text of the original placard was likely to have been written by a secretary or scribe, the more so that of the poster, so the orthography probably did not directly reflect van Outhoorn's personal spelling. Besides that, the decree represented a resolution of the Council of India, the "High Government," so the text should probably be seen as an example of official language use by IndiesDutch functionaries in general.

Memoirs of seventeenth-century visitors to the Archipelago had noted the development of a specific locally assimilated Indies-Dutch community. Their members were known as oorlam "person with experience in the east" (from Malay orang lama "old-timer"), as opposed to oorambaar, or simply

11. Valentyn (1726: 316); Encyclopædie (1917-1921: 1.435); Stapel (1939: 425).

12. Encyclopædie (1917-1921: 4.228-229); Molhuysen et al. (1927: 1196); van Putten (2002: 120).

13. Veth (1850: 24); Freijss (1859: 24-25); Bickmore (1868: 21); Schuchardt (1891: 150). 
baar, "greenhorn" (Malay orang baru "newcomer"). ${ }^{14}$ One feature was the acquisition of Malayisms in their speech. Nevertheless, although oriental loanwords do occur in the Placard Book, the alternatingly spelled word arack arak "arrack," which was already well known in Europe, ${ }^{15}$ is the only one I found in van Outhoorn's 1696 decree. Actually, the latter document seems to avoid any particularities of contemporaneous Indies-Dutch language use altogether. Instead, it exhibits an exaggeratedly presumptuous official style.

This is characterized in particular by an excessive length of sentences that encompass long chains of (occasionally more than a dozen) clauses, making it difficult to follow the line of reasoning. Excluding the header and signature lines (lines. 1-3 and 75-78), the entire main text consists of only nine sentences. The first two encompass 319 and 309 words respectively, and the seven remaining ones an average of ninety-five words each. For comparison, this four-sentence paragraph consists of only seventy-six words.

Comprehensibility is further hampered by frequent replacement of an explicit reference by voorsz[egt] "aforementioned" or deselve "the same," respectively twelve and eleven times. Another feature is frequent and unnecessary use of Latinisms, apparently aimed at demonstrating cultivated language competence. The redundancy of Latinisms is particularly demonstrated by accompaniment of an indigenous Dutch synonym, for example (with text line number on the left):

5: accresseert ofte toeneemt "increases or grows";

36-37: aen ons te demonstreren, ofte over te brengen "to demonstrate, or bring up to us";

60: besit ofte possessie "ownership or possession."

Such synonym pairs occasionally also involved two borrowings:

64: onse ordre en dispositie "our order and disposal."

That this style of duplicate expression was not particular to van Outhoorn (1696) is apparent from the above-cited passages from decrees of Valckenier (publiceeren en affigeeren "make public and display") and van Imhoff (lasten en beveelen wy "we order and command").

A further circumstantiality is naming an action as a succession of the decision to do something and then doing it, for example:

12: $\quad$ hebben goetgevonden te ordonneren, gelijk wij ordonneren bij desen "have considered [it] suitable to ordain, and we hereby do ordain";

26: $\quad$ is met eenen goet gevonden te ordonneren, gelijk bij desen

14. See à Winschooten (1681: 175); van der Sijs (2003: 205-206); Mahdi (2007: 128-131).

15. Marcel Devic (1876: 33-34); Yule \& Burnell (1903: 36); Mahdi (2007: 201-206). 
werd geordonneert "[it] is now found suitable to ordain, and [it] is hereby ordained".

In one quite complicatedly formulated instance, such a sequential expression of an administrative act is (perhaps unwittingly) accompanied by a double negation:

46-47: ... soo is al met eenen goetgevonden een ijgelijk wien het ook soude mogen wesen te verbieden, gelijk verboden wert bij desen, geen hout altoos, onder wat pretext het soude mogen sijn, meer te kappen ofte te halen "... [it] is now found good to forbid any each one whom ever it may be, so be [it] hereby forbidden, to chop or fetch no wood at any time, under whatever pretext it may be."

This abundance of redundant expressive means, explicit repetitions, and unnecessarily circumstantial formulations seems more than one might expect for mere demonstration of own official importance. To my mind, it is an inversion of the oorlam versus [ooram] baar apposition mentioned above. It is not about a newcomer from Europe seeking to demonstrate assimilation to life in the East, but an old-timer feeling obliged to prove his European education by exaggeratedly pretentious language.

This apparently became so common in the writing of VOC officials in the Archipelago, that on September 3, 1735, the annoyed management in the Netherlands ordered that official reports be henceforth kept "short and clear" (kort en klaer), repeating this again on July 19, 1736 (van der Chijs 1885-1900: 4.385 and 396). It was apparently this excessive verbosity too, that motivated the quite drastic abridgement of recorded texts in the Placard Book. Therefore, we are fortunate to have in the present poster an authentic full-length example of that style.

The decree repeats the lengthy paratactic listing "sugar mills, arrack distilleries, chalk burners, brick and tile kilns, as well as lumber mills" in slight variations altogether ten times:

4-5: $\quad$ Suikermolens Arack en kalk branderijen, Item Steen en pannebackerijen mitsgaders Houtsagerijen

7: $\quad$ suijkermaekers, arack en kalkbranders steen en pannebackers mitsgaders houtsagers

14-15: $\quad$ Suikermolens, Arack ofte kalkbranderijen, Steen en pannebackerijen, Item Houtsagerijen

16-17: $\quad$ Suijkermolen, Arak ofte kalkbranden, Steen ende pannebacken, ofte houtsagen

19-20: $\quad$ Suikermolen, Arak ofte kalkbranderijen, Steen ofte pannebackerijen en Houtsagerijen

24: $\quad$ suijkermolens, arak branderijen, kalkovens, steen en 
pannebackerijen Item Houtsagerijen ${ }^{16}$
27-28: $\quad$ suikermolens, arak branderijen, kalkovens, steen en pannebackerijen ofte houtsagerijen

31-32: $\quad$ Suijkermolens, Arak branderijen, kalkovens, Steen en pannebackerijen als Houtsagerijen

34-35: $\quad$ Suijkermolens, Arakbranderijen, kalkovens, steen en pannebackerijen, ofte Houtsagerijen

38-39: $\quad$ Suijkermolens Arak branderijen kalkovens Steen en pannebackerijen, Item Houtsagerijen

Noteworthy here is also the alternation of Latin item (in four lists) with Dutch mitsgaders "so too, as well as" (in one), ofte "or" (three), en "and" (one), and als "as [also]" (one), again demonstrating the redundancy of using the Latinism.

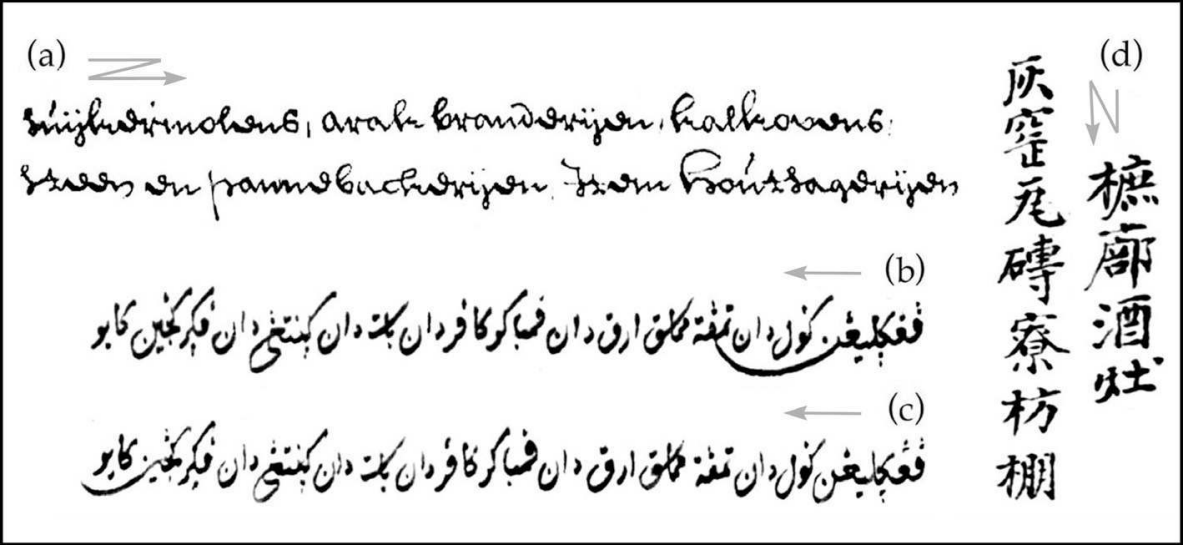

Fig. 2 - Facsimile reproduction of the list of production sites (with the respective reading direction indicated by a grey arrow): (a) in line 24 of the Dutch text, split here into two lines; (b, c) in lines 6 and 28 respectively of the Malay text; (d) in columns 3-4 of the Chinese text.

As though to demonstrate how superfluous this frequent repetition is, the Chinese version, being the one directly addressing those whom the decree actually concerned, conveys the message of the decree with 432 charactersless than one third the number of words of the Dutch text - only citing the paratactic listing twice, uniformly rendered (in right-to-left columns 2 and 3-4; see facsimile of the latter rendering in Fig. 2d):

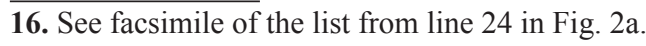


zhèbù jiǔzào huīyáo wăzhuānliáo fāngpéng (樜廊酒灶灰䆙瓦磚寮枋棚). ${ }^{17}$

sugarcane mill, liquor distillery, lime oven, tile brick shack, timber shed.

Indeed, the synopsis of the decree in the Placard Book (van der Chijs 1885-1900: 3.405-407) too is only a little over 400 words long. It furthermore provides the full list of the production sites only once, in the introductory heading. In the further text, the list is referred to representatively as suikermolens, enz. "sugar mills, etc.," and that too only four times. There was no reason not to similarly shorten the list at repeated citation in the original text of the decree. Indeed, in line 30 of van Outhoorn (1696) too, it is given as araksbranderijen Etc: " "arrack distilleries etc.," rendered in the Placard Book as arak-branderijen, enz.

In the Jawi-script Malay version, which apparently strives to approach the Dutch original more closely than the other translations, the listing is nevertheless only repeated eight times (in the lines 6, 12-13, 17, 20, 21-22, 23-24, 25, and 28) uniformly ${ }^{18}$ as:

penggilīngan gūla dān tempat memāsaq āraq dān pembākar kāpur dān bāta dān genting dān pegergajiyan kāyu.

sugar mill and place for cooking arrack and burning lime and brick and tiles and sawing wood.

The excessive verbosity and redundancy of employed expressive means was however not an individual feature of Willem van Outhoorn's writing. As example passages from two other decrees quoted above, as well as the annoyed response of the home office, demonstrate, this seems to have been a common feature of Indies Dutch official texts. However, particularities in expressive means used explicitly in the decree are likely to represent formulations of persons in politically responsible positions, rather than of secretaries or scribes, and van Outhoorn was their chief and personally responsible as signatory.

17. Chinese orthography of the 18 th century, particularly of dialects of the South and the diaspora, is not adequately represented in modern dictionaries. In the poster, the word for "sugarcane," zhè , is not spelled with 熫 (Giles 1912: no. 534 "sugarcane") but with 樜 (ibid. no. 535 "thorny plant, Cudrania triloba Hance") which is nevertheless also glossed "sugarcane" by Wells-Williams (1874: 39), cf. also Couvreur (1904: 472 sub tché). The second character 廍 bù "mill" is a non-standard feature of the Fujian (Hokkien) dialect-also occurring in proper names in Taiwan, see online under https://zh.wikipedia.org/wiki/糖廍—it is neither in Giles (1912) or Wells-Williams (1874), nor in Hanyu Da Zidian (1986-1989). The word yáo "kiln" is spelled with a character closely resembling the non-standard 䆙 (Couvreur 1904: 666 sub Iaô; Hanyu Da Zidian 1986-1989: 4.2725; not in Giles 1912 or Wells-Williams 1874)—cf. the second character from above in the left column of Fig. $2 \mathrm{~d}$-rather than with the more common 窑or窯 (Giles 1912: no. 12,919 \& 12,965, cf. also Wells-Williams 1874: 1075).

18. With variations in the Jawi-script calligraphy that do not show in the transliterationcompare facsimiles of the listing from lines 6 and 28 in Fig. $2 \mathrm{~b}$ and $-\mathrm{c}$ respectively. 


\section{Spelling and Orthographic Particularities of the Text}

Although particular spelling features of the verbatim-quoted passage of the placard possibly represent van Outhoorn's personal style, the likelihood that it actually reflected the personal qualifications of the scribe or secretary are significantly greater. This too however, will open insights into general language use in the colony.

In some aspects, the spelling in van Outhoorn (1696) conforms to contemporaneous developments in the Netherlands. For example, the word for "jurisdiction" is spelled jurisdictie with internal $s$ in the poster as well as in the passage of the placard quoted verbatim in the Placard Book. The spelling in Middle Dutch had been juridictie (Verwijs \& Verdam 1885-1929: 3.1080 sub juridictie), but the $s$ of the Latin precursor was restored during the seventeenth and eighteenth centuries (Woordenboek 1882-1926: 7/1.555), implying that the involved Indies-Dutch writers were up-to-date on this point.

In those days, the spelling of words tended to variegate even in print publications. In the poster text too, one finds examples like ijgelijk (twice) ijegelijk (once) "each, every", tijt (twice) tijd (three times) "time," cf. also suiker (four times) suijker (six) "sugar" in the production-site listings quoted above. These variants are all represented in Verwijs \& Verdam (18851929: sub iegelijc, suker, and tijt). Noteworthy are some consistent spelling differences between poster (cited with line-numbers) and verbatim-quoted part of the placard, compare:

8-10: $\quad$ voorsz: neringen ... moeijelijke processen krakelen en sware banquerotten

placard: voorsz.neeringen ... moeyelycke processen, crackeelen ende swaere bancqueroeten

aforementioned businesses ... difficult processes, quarrels and severe bankruptcies

30-38: de Jurisdictie van den Baljuw ... het ware getal van Soodanige

Suijkermolens, ... met bijvoeginge waar deselve sijn gelegen, en wanneerse sijn opgeregt ... soodanigen dispositie over ijder van deselve te laten gaen, als wij dat ten beste onser Ingesetenen, sullen oordelen en bevinden te behoren

placard: de jurisdictie van den Bailluw ... het waere getal van sodanighe suykermolens, ... met byvoeginge, waer deselve syn gelegen en wanneerse zyn opgerigt ... sodaenighe dispositie over yeder van deselve laeten gaen, als wy dat ten beste onser ingesetenen, sullen oordeelen ende bevinden te behooren the jurisdiction of the Bailiff ${ }^{19} \ldots$ the true number of such sugar mills, ... with addition of where these are located, and when they were set up... proceed

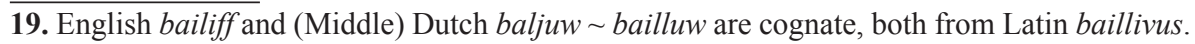


with such disposition over each of them, as we shall judge and decide to be in the best interest of our residents

62-66: behoorlijke aentekeninge te laten doen waar soodanige landen sijn gelegen, ... daarop aftewagten ende dat onaengesien Imand ... eenig besit vergunt ofte gegeven mogten sijn 't welk dan bij voorsz: aentekeninge mede voorgestelt

placard: behoorlycke aenteeckeninge laeten doen, waer sodanige landen zyn gelegen, ... daerop aff te wachten ende dat onaengesien yemandt ... eenich besit vergunt ofte gegeven mochte zyn, 't welcke dan by voorsz. aenteeckeninge mede voorgestellt

let proper notation be made where such lands are located, ... await and regardless of whether somebody... may have been granted or given any possession, the which should then have been presented or declared at aforementioned notation

The consistent $i j$ of the poster as against $y$ of the placard were alternative renderings of one and the same, but the former is more consistent with modern spelling. The initial $\mathrm{z}$ in the spelling of $z y n$ "his" in the placard, however, conforms better to modern spelling than the $s$ in sijn of the poster. The initial of a word in the midst of a sentence in the poster is occasionally written with a capital letter, as one can see in several text-passages quoted above (also in the paratactic listings of production sites). This is not so in the verbatim-quoted passage of the placard which follows modern orthographic rules on this point, capitalizing only the initial of the first word in a sentence, proper names and titulary terms.

With regard to poster/placard baljuw / bailluw "bailiff" and banquerotten / bancqueroeten "bankruptcies," Verwijs \& Verdam (1885-1929: sub baliu) note both variants of the former, while those of the latter are attested to in Woordenboek (1882-1998: sub bankbreuk and bankroet), but the base-final oe in the placard conforms better to modern bankroet.

A Dutch vowel before an intervocalic consonant is long by default, and vowel length is therefore not explicitly indicated in Modern Dutch spelling. One frequent spelling particularity in the above quotation pairs is that long vowels are explicitly spelled as such before an intervocalic consonant in the placard, but not in the poster. In this respect the spelling in the poster is more modern than that in the placard, compare:

poster/placard: behoren / behooren "belong, should be"; imand / yemandt "somebody"; krakelen / crackeelen "quarrels"; laten / laeten "to let"; neringen / neeringen "businesses"; $\quad$ oordelen / oordeelen "judge"; sware / swaere "heavy." 
In some instances, however, the situation is ambiguous, e.g.

$$
\text { soodanige } \sim \text { soodanigen / sodanighe } \sim \text { sodaenighe "such." }
$$

For some entries, the Middle Dutch dictionary of Verwijs \& Verdam (18851929) does not include variants with explicit long-vowel notation (for example ibid.: sub behoren, and sware). In most other instances, however, such variant spelling was attested to, for example oordeelen (sub delen), eenich eenig (sub enich), krackeelen $\sim$ krakkeelen (sub crakeel), neeringhe $\sim$ neeringen (sub neringe), sodaenigh (sub sodanich), or [aen-]teekeninge (sub tekeninge), and in the case of imand / yemandt explicit indication of vowel length even was the rule (ibid.: sub ieman).

By contrast, one spelling error in the Dutch text of the poster is that an internal -cht- cluster (read $[\chi \mathrm{t}]$ ) is consistently spelled -gt- (as if it were to be read $[\gamma t])$, as in aftewagten "await" and mogten "may have." ${ }^{20}$ In the dictionary of Verwijs \& Verdam (1885-1929: sub wachten and mogen) for Middle Dutch, and in Woordenboek (1882-1998: sub afwachten and mogen) for New Dutch, the cluster is spelled exclusively -cht-, never -gt-. Remarkably, the same words are spelled with -cht-in the verbatim-quoted passage of the placard in van der Chijs (1885-1900: 3.406).

From the above it seems likely that orthographic discrepancies between the poster and the verbatim-quoted part of the placard reflect personal spelling customs of the respective scribes or copyists. In the main, the spelling in the poster seems to be more up-to-date than that in the placard, but in some points, e.g. capitalization of word initial letters, the use of initial $s$ - in place of $z$-, or of internal - $g t$ - in the poster, it is the other way round.

To have comparative material for official texts written in the East in that period, I accessed a contemporaneous six-page manuscript at the Nationaal Archief in The Hague, a 1696 elucidation of a 1688 instruction of the VOC directors, compiled by J. Donker (1696). A zigzag zed occurs there in several words, amongst others zaken "matters," zal "shall," zelven "same," zij "they," zijn "are, be." Noteworthy is that the -cht- cluster of received spelling is consistently replaced by -gt-, as in afwagten "await," kragtige "strong," nogtans "nevertheless," lijffwagten "life guards," verrigten "carry out." Hence, Donker uses word-initial $z$ - like the writer of the placard, but has wordinternal cluster -gt- instead of -cht- like the writer of the poster. The use of $s$ - instead of $z$ - or of -gt-instead of -cht- was thus not consistent amongst the Indies Dutch, regardless of whether the spelling of the placard is that of van Outhoorn himself, or of a scribe.

One feature of the spelling in Outhoorn (1696), which cannot be compared with that of the printed placard passage, is the use and form of some hand-

20. The cluster in the former is part of the word base (-wacht-), but not in the latter (word base $m o g-$ ) which contains the past tense marker $-t-$. 


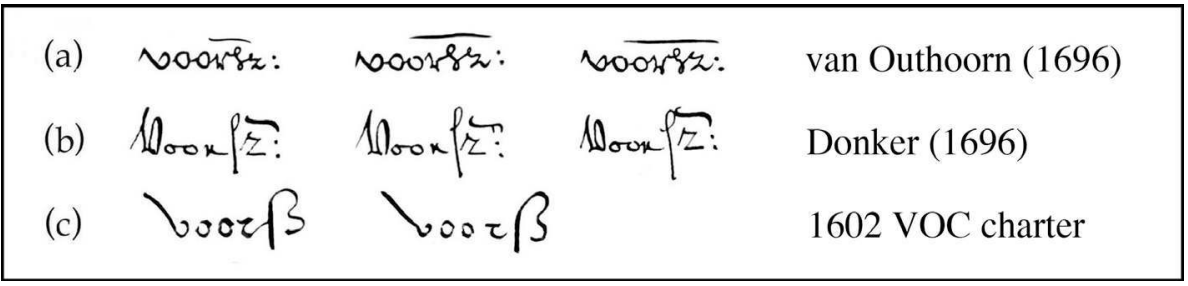

Fig. 3 - Examples of voorsz. as written in: the van Outhoorn (1696) poster; the Donker (1696) manuscript; and the 1602 VOC charter.

written letters. For reason of space, I will restrict myself to the use and form of the letter zed $(z)$ here. ${ }^{21}$ It only occurs in the abbreviation voorsz. (for voorszegt "aforementioned"). The zed in earlier Dutch texts resembled a three (3), ${ }^{22}$ and the ess-zed cluster in voorsz. was typically rendered as ligature of a long (or descending) ess $(f)$ with that 3 -formed zed, as in modern German Eszett $(\beta)$. The abbreviation was still rendered in this old way as voor $\beta$ on the first page of the 1602 charter of the VOC (see Fig. 3c). ${ }^{23}$

On the Outhoorn (1696) poster, however, the ess-zed cluster was written as sequence of a rounded ess $(s)$ and a zigzag zed $(z)$, hence quite up-to-date (see Fig. 3a). In Donker (1696) cited above for comparison, a zed is consistently written as zigzag, also in the abbreviation voorsz. (twenty-four times). But the ess in the final cluster of the latter is spelled as long (descending) ess, resulting in $f z$ rather than $s z$ (see Fig. 3b). Outhoorn (1696) and Donker (1696) have in common, that a horizontal line is drawn over the word-final $s z$ cluster.

In the main, one may probably conclude that local particularity of "officialese" style in the colony was mainly limited to excessive verbosity and pretentious modes of expression. For the rest, the text does not feature distinct Indies-Dutch lexical or spelling deviations, but appears somewhat non-uniform, allowing for variation in individual custom of the writers. In some instances, such as erroneous spelling of the -cht- cluster as -gt-, or explicit indication of vowel length before an intervocalic consonant, it is quite obsolete. In some other instances, it goes abreast with latest developments in spelling in the Netherlands, as demonstrated amongst others by the spelling of jurisdictie or the zigzag rendering of a zed, particularly in a final $s z$ cluster.

\section{Conclusions.}

The discovery of a 1696 official poster of a decree of a Batavian governor general in a library in Berlin is quite intriguing, the more so because the decree

21. Note the particular form of $e, r$, or word-final $-s$ in the Fig. 2a facsimile. It was common in manuscripts of that period, and not particular to van Outhoorn (1696).

22. Horsman et al. (1984: 18); Dekker et al. (1992: xxiii and xxvii).

23. Based on reproductions in Stapel (1939: 17) and Gaastra (1991: 21). 
had apparently not been obeyed, but simply ignored. A closer examination revealed that the decree was issued in a critical period of VOC government, marked by serious internal irregularities. Bearing in mind the successful military, political, trade monopolist, and other achievements of the VOC in the Archipelago, that development seems quite surprising. But the existence of active as well as passive corruption of the VOC hierarchy by external business interests as well as through illegal activity of its functionaries is meanwhile well established in the literature. ${ }^{24}$

Perhaps of greater interest are socio-linguistic insights disclosed by this unique example of a full-length original official document. It had been well known that the seventeenth-century Dutch community in the Archipelago had been characterized by an apposition of old-timers (oorlam) versus newcomers ([ooram]baar). In this, the newcomers aspired to acquire the linguistic and other features of old-timers as soon as possible. As noted above, the presently inspected document discloses an opposite tendency, suggesting that the oldtimers versus newcomers constellation was no longer characteric of the Indies Dutch, or at least not of employees and functionaries of the government hiearchy. In this, one should apparently differentiate between persons from upper and lower ranks.

It was the high-ranking functionaries who were responsible for the formulations in official documents and it is hardly surprising that it was these who strived to demonstrate their European cultivation to the home office by exaggerated verbosity. The actual writing was performed by lower ranking scribes. These apparently demonstrated their European cultivation by following up-to-date orthographic features to the best of their individual knowledge of contemporanous developments in the homeland.

The oorlam versus [ooram]baar constellation was mainly observed in the seventeenth century. In the subsequent time, use of particularly the latter term was mainly characteristic of seamen's language, and of Afrikaans spoken in South Africa. ${ }^{25}$ In view of the 17th versus 18 th century "up-and-down" apposition, of which the reversal dates from the last two decades of the 17th century, it seems possible that this was also reflected in replacement of that oldtimer/newcomer apposition by the new tendency towards exaggerated display of European culture.

Nevertheless, this must remain a speculation, because one single document, even as voluminous as the Outhoorn (1696) poster, cannot be sufficient basis for such fargoing conclusions. Be that as it may, the study of the Dutch text of the rediscovered poster has led to insights into several interesting and hitherto unnoticed socio-linguistic aspects of the period of VOC government in Java.

24. Cf. van Putten (2002: 105-106, 120, 139-140); Day (1904: 101-105); Vlekke (1965: 213). 25. See à Winschooten (1681: 175), and Bosman (1916:51 sub baar). 


\section{Acknowledgements.}

I am indebted to Edwin Wieringa and Thoralf Hanstein, without whose discovery this article would not have been possible. I wish to furthermore thank the Orientabteilung of the Staatsbibliothek zu Berlin for an early facsimile scan of the 1696 poster. My thanks also go to Annabel Gallop for helping me with the Malay text, to Claudine Salmon and Yunpei Deng who helped me with the Chinese text, and to Roderick Orlina, David Moeljadi and Tom Hoogervorst for helping out with Chinese character fonts.

I am particularly grateful to Gerhard Ertl, former director of the Physical Chemistry Department of the Fritz Haber Institute, Berlin, and the present director Martin Wolf, for the generous opportunity to use Department facilities in my linguistic and culture-historical studies, and also to Marcel Krenz, Albrecht Ropers, and Frank Quadt, for invaluable technical support.

\section{Bibliographic references.}

Baladouni, Vahé, 1983, “Accounting in the early years of the East India Company," Accounting Historians Journal 10/2:63-80.

Balk, G.L., F. van Dijk, \& D. J. Kortlang, 2007, The Archives of the Dutch East India Company (VOC) and the Local Institutions in Batavia (Jakarta). With contributons by F. S. Gaastra, Hendrik E. Niemeijer, P. Koenders. Leiden: Brill.

Bickmore, Albert S., 1868, Travels in the East Indian Archipelago. London: John Murray.

Bosman, Daniël B., 1916, Afrikaans en Maleis-Portugees. Groningen: P. Noordhoff.

Boxer, C.R., 1965, The Dutch Seaborne Empire 1600-1800. London: Hutchinson.

Brumund, J. F. G. , 1864, "Bijdragen tot de Geschiedenis der Kerk van Batavia," Tijdschrift voor Indische Taal-, Land- en Volkenkunde 13:1-189.

Chijs, J.A. van der, 1885-1900, Nederlandsch-Indisch Plakaatboek, 1602-1811, vols. 1-17. Batavia: Landsdrukkerij / 's Hage: M. Nijhoff.

Couvreur, F.S., 1904, Dictionaire classique de la langue chinoise. Ho Kein Fou: imprimerie de la mission catholique.

Day, Clive, 1904, The Policy and Administration of the Dutch in Java. London: Macmillan.

Dekker, C., R. Baetens, S. Maarschalkweerd-Dechamps, 1992, Album palaeographicum XVII Provinciarum / Paleografisch album van Nederland, België, Luxemburg en NoordFrankrijk / Album de paléographie des Pays-Bas, de Belgique, du Luxembourg et du Nord de la France. Turnhout: Brepols / Utrecht: H\&S.

Donker, J., 1696, “Ampliatie en elucidatie vande Instructie bij de vergadering vande Seventienen opgesteld den 30. Maart 1688. Voorde Indepen[den]ce fiscaals in Indien," Manuscript in dossier no. 3 of: Inventaris van archivalia afkomstig van de Hoge Regering, 1602-1827, nummer toegang 1.04.17, inventarisnummer 3, at Nationaal Archief (NA), Den Haag.

Devic , Marcel L., 1876, Dictionaire étymologique des mots français d'origine orientale. Paris: Imprimerie Nationale (réimpression 1965, Amsterdam: Oriental Press).

[Encyclopædie], 1917-1921, Encyclopcedie van Nederlandsch-Indië: vol. 1, A-G, J. Paulus (ed.); vol. 2, H-M, S. de Graaff \& D.G. Stibbe (eds.); vols. 3, $N-$ Soema, \& 4, Soemb - Z, D.G. Stibbe (ed.). 's-Gravenhage: Martinus Nijhoff / Leiden: N.V. v/h E.J. Brill.

Freijss, J.P., 1859, Proeve ter beantwoording der vraag: wat ter bevordering van beschaving in 
Nederlandsch-Indië kan worden gedaan. Amsterdam: H. Hoveker.

Gaastra, Femme S., 1991, De geschiedenis van de VOC. Zutphen: Walburg Pers.

—, 2002, "Succesvol ondernemerschap, falend bestuur? Het beleid van de bewindhebbers van de VOC, 1602-1795," in Leonard Blussé \& Ilonka Ooms, eds., Kennis en Compagnie. De Verenigde Oost-Indische Compagnie en de moderne Wetenschap, pp. 55-70. [Amsterdam]: Uitgeverij Balans.

Giles, Herbert A., 1912, A Chinese-English Dictionary. Shanghai / Hongkong / Singapore / Yokohama: Kelly \& Walsh / London: Quarritch.

Haan, F. de, 1910-1912, Priangan: De Preanger-Regentschap onder het Nederlandsch Bestuur tot 1811. Uitgegeven door het Bataviaasch Genootschap van Kunsten en Wetenschappen, volumes 1-4. Batavia: G. Kolff / 's-Gravenhage: Martinus Nijhoff.

—, 1935, Oud Batavia. 2e herziene druk. Bandoeng: A.C. Nix.

[Hanyu Da Zidian], 1986-1989, Hànyǔ Dà Zìdiăn (漢語大字典). Vols. 1-8. Wuhan: Hubei cishu chubanshe.

Hooyman, Jan, 1781, "Verhandeling over den tegenwoordigen staat van den Land-Bouw," in de Ommelanden van Batavia, Verhandelingen van het Bataviaasch Genootschap, der Konsten en Weetenschappen 1:173-262.

Horsman, P.J., Th.J. Poelstra, \& J.P. Sigmond, 1984, Schriftspiegel: Nederlandse paleografische teksten van de 13de tot de 18de eeuw. Zutphen: Uitgeverij Terra Zutphen.

Jacobi, Christiaan, 1784, "Om het toeneemend houtgebrek der zuiker-molens," in de bovenlanden, spoedig en duurzaam te verhelpen, Verhandelingen van het Bataviaasch Genootschap, der Konsten en Wetenschappen 2: Bekroonde antwoorden en berichten [supplement with separate page numbering].

Jonge, J.K.J. de, 1875, De opkomst van het Nederlandsch gezag in Oost-Indie, deel 8 / De opkomst van het Nederlandsch gezag over Java, deel 5. Verzameling van onuitgegeven stukken uit het Oud-Koloniaal Archief. 's-Gravenhage: Martinus Nijhoff.

Leur, J.C. van, 1955, Indonesian Trade and Society. Essays in Asian Social and Economic History. The Hague / Bandung: van Hoeve.

Mahdi, Waruno, 2007, Malay Words and Malay Things: Lexical Souvenirs from an Exotic Archipelago in German Publications before 1700. Frankfurter Forschungen zu Südostasien 3. Wiesbaden: Harrassowitz.

Molhuysen, P.C., P.J. Blok, \& K.H. Kossman, eds., 1924, Nieuw Nederlandsch biografisch woordenboek, vol. 6. Leiden: A.W. Sijthoff.

—, 1927, Nieuw Nederlandsch biografisch woordenboek, vol. 7. Leiden: A.W. Sijthoff.

Nagel, Jürgen G., 2007, Abenteuer Fernhandel: Die Ostindienkompanien. Darmstadt: Wissenschaftliche Buchgesellschaft.

Ong Eng Die, 1943, Chineezen in Nederlandsch-Indië: Sociografie van een Indonesische bevolkingsgroep. Sociographische Monografieën onder red. van H.N. ter Veen, 2. Assen: van Gorcum.

Outhoorn, Willem van, 1696, Poster dated 24 July 1696 with text of his 26 June 1696 decree and Malay, Javanese and Chinese translations. Countersigned by C. van Swoll. Berlin: Staatsbibliothek zu Berlin - Preußischer Kulturbesitz, benchmark: Ms. or. fol. 547 b.

Putten, Leo P. van, 2002, Ambitie en onvermogen: Gouverneurs-generaal van NederlandsIndië 1610-1796. Rotterdam: ILCO-productions.

Rijnenberg, J., 1867, Geschiedenis der Nederlanders op Java, of in den Nederlandsch OostIndischen Archipel. Semarang: de Groot, Kolff.

Robins, Nick, 2006, The Corporation that Changed the World: How the East India Company Shaped the Modern Multinational. London / New York: Pluto Press.

Schuchardt, Hugo, 1891, Kreolische Studien, IX. Über das Malaioportugiesische von Batavia und Tugu. Sitzungsberichte der Kais. Akademie der Wissenschaften in Wien, 
Philosophisch-Historische Classe 72, Abhandlung 12. Wien: F. Tempsky.

Sijs, Nicoline van der, ed., 2003, P. J. Veth. Uit Oost en West. Verklaring van 1000 woorden uit Nederlands-Indië. Met aanvullingen van H. Kern en F. P. H. Prick van Wely. Amsterdam: L.J. Veen.

Stapel, F.W., 1939, De oprichting der Vereenigde Oostindische Compagnie; De Nederl. Oostindische Compagnie in de zeventiende eeuw. Geschiedenis van Nederlandsch Indië 3. Amsterdam: Joost van den Vondel.

Steins Bisschop, Bas T.M., \& Tjalling Wiersma, 2002, "De moderne N.V. als Compagnie," in Leonard Blussé \& Ilonka Ooms, eds., Kennis en Compagnie. De Verenigde Oost-Indische Compagnie en de moderne Wetenschap, 37-54. [Amsterdam]: Uitgeverij Balans.

Valentyn, François, 1726, Beschryving van Groot Djava, ofte Java Major [...]. Part 4 in Oud en Nieuw Oost-Indiën. Dordrecht: Joannes van Braam / Amsterdam: Gerard onder de Linden.

Verwijs, E., \& J. Verdam, 1885-1929, Middelnederlandsch woordenboek, vols. 1-9. 's-Gravenhage: Martinus Nijhoff.

Veth, P.J., 1850, Over den toestand en de behoeften van het onderwijs der jeugd in Nederlandsch Indië. Anspraak gehouden bij de opening van de algemeene vergadering der maatschapij: Tot nut van 't algemeen, 13 Augustus 1850. [Amsterdam]: Spin \& zoon.

Vlekke, Bernard H.M., 1965, Nusantara - A History of Indonesia. Sixth impression. The Hague: W. van Hoeve [first impression 1943].

Wells-Williams, S., 1874, A syllabic dictionary of the Chinese language, arranged according to the Wu-Fang Yuen Yin, with the pronunciation of the characters as heard in Peking, Canton, Amoy, and Shanghai. Shanghai: American Presbyterian Mission Press.

Winschooten, Wigardus à, 1681, Seeman: Behelsende Een grondige uitlegging van de Neederlandse Konst, en Spreekwoorden, voor soo veel die uit de Seevaart sijn ontleend, en bij de beste Schrijvers deeser eeuw gevonden werden. Leiden: Johannes de Vivie.

[Woordenboek], 1882-1998, Woordenboek der Nederlandsche Taal, vol 1, A-Ajuin, ed. M. de Vries \& L.A. te Winkel; vol 2, Akant - Berispelijk, ed. M. de Vries, \& A. Kluyver; vol. 7/1, J-Keurmede, ed. A. Beets; vol. 9, $M$-Nymph, ed. A. Kluyver, A. Lodewyckx, J. Heinsius, \& J.A.N. Knuttel. 's-Gravenhage: Martinus Nijhoff / Leiden: A.W. Sijthoff.

Yule, Henry, and A.C. Burnell, 1903, Hobson-Jobson: A Glossary of Colloquial Anglo-Indian Words and Phrases, and of Kindred Terms, Etymological, Historical, Geographical, and Discursive. New ed. edited by William Crooke. London: Murray (facsim. repro. 1989, Calcutta: Rupa \& Co.); (1 $1^{\text {st }}$ ed. 1886). 


\section{Appendix 1. The Dutch teXt Of The POSTER. ${ }^{26}$}

\section{[1] Willem van Outhoorn Gouverneur Generael [2] ende de Raden over den Staat van de Generale Nederlandse Geoc-[3] troijeerde Oost-Indische Compagnie in India doen te weten.}

[4] Alsoo het getal der Suikermolens Arack en kalk branderijen, Item Steen en pannebackerijen mitsgaders Hout- [5] sagerijen binnen deser Stede Jurisdictie nog dagelijx in diervoegen accresseert ofte toeneemt, dat niet alleen te vresen [6] sij het eerlange ofte in weijnige Jaren sal manqueren aen het vereijste branthout tot dagelijx gebruijken andere nodige dienste, [7] maar dat ook het presente getal van de suijkermaekers, arack en kalkbranders steen en pannebackers mitsgaders houtsagers [8] reets te menigvuldig sijnde de een den anderen in voorsz: neringen bronnen te bederven waar door alsoo aen deselve tamelijke [9] Capitalen moeten werden te koste gelegt, niet anders is te verwagten als moeijelijke processen krakelen en sware banque- [10] rotten, waarvan de beginselen voor het Collegie van Heeren Schepenen deser stede aldagelijx werden vernomen, en dienvolgende [11] hoe eer hoe beter dient voorsien te werden, tegens de disordres die uijt het geene voorsz: is staen voor te komen, soo ist dat wij [12] na rijpe deliberatie in Rade van India hebben goetgevonden te ordonneren, gelijk wij ordonneren bij desen, dat van heden aff [13] niemand onser Ingesetenen, ofte alhier remorerende, wien het ook soude mogen wesen, binnen deser stede Jurisdictie, 't sij [14] binnen de stad, off ten platten lande, Sal vermogen opteregten, een ofte meer Suikermolens, Arack ofte kalkbranderijen, [15] Steen en pannebackerijen, Item Houtsagerijen, buiten de gene die reets in haar volkomen wesen en gebruijk sijn, dan met [16] onse kennisse en toestemminge even gelijk niemand die eenige onvolmaakte werken tot voorsz: neringen, 't sij Suijker[17] molen, Arak ofte kalkbranden, Steen ende pannebacken, ofte houtsagen, althans onderhanden heeft, daarmee sal vermogen [18] voort te varen, alvorens hij daar toe Insgelijx onse permissie versogt, ende verkregen sal hebben, ende dat op een boete van [19] tweehondert Rijxd: ${ }^{r s}$ te verbeuren bij den Eijgenaer van ijder Suikermolen, Arak ofte kalkbranderijen, Steen ofte pannebacke-[20] rijen en Houtsagerijen die bevonden sal werden tegen dese onse ordre buijten verlof opgeregt ofte volbouwt te sijn buijten nog [21] dat dese hoe ook de facto weder afgebroken ende weggenomen sullen moeten werden.

[22] eog op dat ontrent het gene voorsz: is, tot welwesen deser gemeente, niet alleen te beter toesigt gehouden en alle over- [23] tredinge te gemackelijker geweert mag werden, maar dat wij ook eenmal mogen geraken aen de kennisse van het ware getal [24] van alle de suijkermolens, arak branderijen, kalkovens, steen en pannebackerijen Item Houtsagerijen binnen deser stede [25] Jurisdictie, om daar uijt te konnen oordelen en besluijten welke en hoe vele daarvan in wesen gelaten off wel als ondienstig afge[26] broken en ingetrocken sullen dienen te werden; Soo is met eenen goet gevonden te ordonneren, gelijk bij desen werd geordonneert [27] dat een ijgelijk die binnen deser

\footnotetext{
26. This is the Dutch text in the far left column of the four-column poster. Header and signature lines, written in large letters in the original, are rendered here in boldface. Uncertain readings are between figured parentheses $\{\ldots\}$. Beginnings of original text lines are indicated here by the line number placed between brackets [...]. An English translation follows in Appendix 2.
} 
stede Jurisdictie 't sij binnen de stad ofte ten platten lande een ofte meer suikermolens, arak bran- [28] derijen, kalkovens, steen en pannebackerijen ofte houtsagerijen, ende dat in het geheel off ten dele volmaakt besit ofte deselve [29] in eijgendom toebehoren, sig binnen den tijt van een maand na den datum en publicatie deses sal, hebben te addresseren te [30] weten de eijgenaers van soodanige araksbranderijen Etc: ${ }^{a}$, als binnen dese stad ende suider voorstad, ofte de Jurisdictie van [31] den Baljuw sijn gelegen, aen den Secretaris van Heeren Schepenen deser stede Joannes Mouris dog van alle verdere Suijker- [32] molens, Arak branderijen, kalkovens, Steen en pannebackerijen als Houtsagerijen die buijten deselve, ten platten lande onder [33] de Jurisdictie van den Lantdrost sijn gelegen en opgeregt aen den Secretaris van Heeren Heemraden deser ommelanden [34] Samuel Hoorn, om aen deselve respective optegeven, het ware getal van Soodanige Suijkermolens, Arakbranderijen, [35] kalkovens, steen en pannebackerijen, ofte Houtsagerijen, als hij sal besitten ofte hem in eijgendom bekomen, met bijvoeginge [36] waar deselve sijn gelegen, en wanneerse sijn opgeregt, om sulx gesamentlijk, na 't verloop van voorsz: tijt, aen ons te demon- [37] streren, ofte over te brengen, en als dan soodanigen dispositie over ijder van deselve te laten gaen, als wij dat ten beste onser [38] Ingesetenen, sullen oordelen en bevinden te behoren. Op pone dat alle soodanige Suijkermolens Arak branderijen kalk- [39] ovens Steen en pannebackerijen, Item Houtsagerijen, die nae 't verloop van voorsz: maand, Buiten de aengevinge sullen [40] werden ontdekt en uijtgevonden door den Eijgenaer, off wel ten eersten sullen moeten werden afgebroken en weg geno- [41] men, off wel denselven Soodanigen Arbitralen Correctie werden opgelegt alsdan na bevindinge van saken sal werden [42] geoordeelt te bekoren.

[43] En dewijle de stoutheijt en baatsugt van vele luijden Soo verre gaat, dat deselve tot voorsz: neringen ende andere gebruijken, [44] van Comp: $\boldsymbol{e}$ nog onuijtgegevene landen, als hun eijgen, derven weghalen het daar op staande hout, waar door deselve,

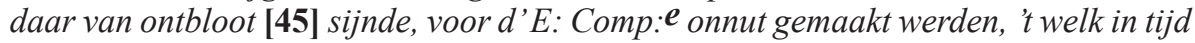
en wijle al mede sijn ongelegentheijt voor deselve soude veroor- [46] saeken, soo is al met eenen goetgevonden een ijgelijk wien het ook soude mogen wesen te verbieden, gelijk verboden wert bij [47] desen, geen hout altoos, onder wat pretext het soude mogen sijn, meer te kappen ofte te halen van landen die\{s'\} E: Comp: $\boldsymbol{e}$ nog toe [48] behoren, en waar van de possessie haar op een wettige wijsen niet en is vergunt, op pone van een boete van Tweehondert [49] Rijxd: ${ }^{r s}$ off wel andere arbitrale correctie voor den gene die daar op betr\{a\}pt ofte bevonden sal werden na gelegentheijt van per- [50] soonen en saken.

[51] Maar alsoo bij vele luijden die in beeldinge ofte meijninge souden konnen sijn dat wanneer sij hun elders op 's Comp:e landen terneder [52] geset ofte [d] eselve onder haar geslagen hebbende een ofte meer Jaren verlopen sijn sonder daarin verhindert te wesen sulx geagt [53] soude dienen te werden voor een genoegsame regt van eijgendom ten minsten possessie waar in sij hun nogtans grotelijx souden [54] abuseren dewijl niemant gerekent sal werden een wettig regt van eijgendom op eenig land te hebben dan waar van de uijtgifte bij [55] donatie of erf brieven van dese Regeringe konnen werden vertoont of wel wettelijk transport voor gecommitteerde schepenen [56] gelijk ook niet van aennemelijke possessie dan bij wettige bescheijden door Heeren Heemraden verleent. En daarom als ook [57] om eenmaal te geraken uijt de presente duijsterheijt en verwerringe ontrent de kennisse der wettigheijt van 


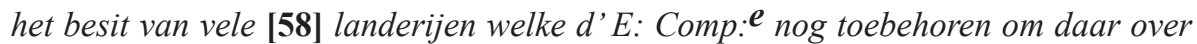
eens het nodige besluijt voor het aenstaende te konnen nemen, soo is met [59] eenen in Rade van India gearresteert en goetgevonden te ordonneren, gelijk bij desen geschiet dat een ijegelijk die eenig regt van [60] besit ofte possessie sal vermenen te hebben op eenig land het welke bij behoorlijke brieven van ons ofte onse voorsaten in dese

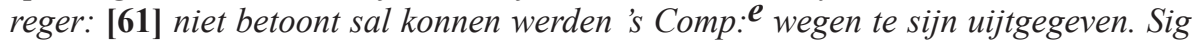
binnen den tijd van Ses maanden na den datum en pu- [62] blicatie deses sal hebben te addresseren aen den Secretaris van Heeren Heemraden deser ommelanden Samuel Hoorn om be- [63] hoorlijke aentekeninge te laten doen waar soodanige landen sijn gelegen, wanneer en op wat fondament sij hun deselve ter- [64] neder geset of wel possessie daarvan genomen hebben om wijders onse ordre en dispositie daarop aftewagten ende dat onaengesien [65] Imand bij monde of geschrifte door Heeren Heemraden of eeniger leden uijt deselve eenig besit vergunt ofte gegeven mogten sijn [66] 't welk dan bij voorsz: aentekeninge mede voorgestelt ende opgegeven sal moeten werden op pone dat na verloop van voorsz: tijd de gene [67] die sig niet aengegeven en voorsz: aentekening versuijmt sal hebben in sijn pretentie niet gehoort en boven nae gelegentheijt [68] gecorrigeert sal werden.

[69] En op dat niemand van het gene voorsz: is eenige Ignorantie soude mogen pretenderen hebben wij goetgevonden dese waarschouwinge [70] en advertentie boven de gewoone publicatie, ook inde Nederlandse, Chinese, Maleijtse en Iavaanse Tale, alomme ter plaatse daer [71] sulx behoort en gebruijkelijk sij te doen affigeren. Bevelende dierhalve, de beijde Collegien van Justitie, Item Heeren Heem- [72] raden deser ommelanden soo veel hun officie aen gaat, mitsgaders de Respective officieren der Justitie met name den Advocaet Fisc:l [73] van India, den Baljuw en Landdrost, Ider in hare Jurisdictie op de Executie van het gene voorsz: is behoorlijk te letten en doen [74] letten, mitsgaders tegen de overtreders procederen soo't behoort.

[75] Gegeven in't Casteel Batavia op't Eijlant Groot Java desen 24: Julij 1696 [76] [77] Ter Ordonnantie van Hoog Gem: Haar $\mathrm{Ed}^{e}$ : W: van Outhoorn $\{? e d\}$

[78] C, van Swoll Clerck

\section{List of abbreviations occurring in the text, and their respective expansions:}

$\left[\left[d^{\prime}\right]\right.$ E: $]$ Comp:e
eog
Etc: $a$
Fisc:l
Rijxd:rs
voorsz:

[[de] Edele $]$ Compagnie "[[the] Noble] Company" ende ook gelijk "and also right away" Et cetera "etc."

Fiscael (modern Fiscaal) "officer of justice, prosecutor"

Rijksdaelders (modern Rijksdaalders) "Rixdollars" voorszegt "aforementioned" 


\section{Appendix 2. Translation of the Dutch text}

Willem van Outhoorn Governor General and the Councils over the State of the General Netherlands Chartered East-Indies Company in India [hereby] make known:

As the number of sugar mills, arrack distilleries and chalk burners, so too brick and tile kilns as well as lumber mills inside this municipal jurisdiction increases or grows at such a rate every day, that it is not only to be feared that shortly or in a few years there will be a deficiency of required firewood for daily use for other necessities, but as also the present number of sugar producers, arrack distillers and chalk burners, brick and tile bakers as well as wood sawyers, is already too numerous, the aforementioned businesses spoiling the sources for one another so that considerable capital needs to be spent for it, nothing is to be expected other than difficult quarrelsome processes and severe bankruptcies, the beginnings of which are already perceived every day by the College of Gentlemen Aldermen ${ }^{27}$ of these municipalities, in consequence of which it is the sooner the better that steps against the disorders resulting from aforementioned circumstances are taken, hence it is that after mature deliberation in the Council of India we consider suitable to ordain, and hereby do ordain, that as of today nobody from amongst our residents, or is staying here, whoever it may be, within the jurisdiction of these municipalities, be it within the city, or in the countryside, will be allowed to set up one or more sugar mills, arrack distilleries or chalk burners, brick and tile kilns, so too lumber mills, beyond those that already are in complete existence and use, other than with our knowledge and permission as also nobody who is at least working on any incomplete works for aforementioned businesses, be it sugar mills, arrack distilleries or calk burners, brick and tile kilns or lumber mills, shall be allowed to continue with it, before he also applied for our permission, and shall have obtained it, and that a fine of two hundred Rixdollars is to be forfeited by the owner of each sugar mill, arrack distillery or chalk burners, brick and tile kilns and lumber mills that shall be found to have been set up or built without permission contrary to this our order besides that these will under any circumstance have to be dismantled and taken away.

And insofar as that which concerns the aforementioned, for the wellbeing of the community, not only to keep under better supervision and that all transgressions may be more easily prevented, but that we also gain knowledge of the true number of all sugar mills, arrack distillers, chalk ovens, brick and tile kilns so too lumber mills inside this municipal jurisdiction, so as to be able to judge and decide from that how many of them be left as they are or be dismantled and retracted as superfluous; so it is now found fit to ordain, and it is hereby ordained that everyone who entirely or partly owns within this

27. Schepen (plural schepenen), cognate with French échevin and German Schöffe, could be translated as "alderman" or "magistrate." The former translation, applied here, is also preferred by Balk et al. (2007: 67). 
municipal jurisdiction, be it inside the city or in the countryside, one or more sugar mills, arrack distilleries, chalk burners, brick and tile kilns or lumber mills, or have such same in their possession, shall within the time of one month after the date and publication of this have addressed to be known as owners of such sugar mills etc., within this city and southern suburb, ${ }^{28}$ or lying in the jurisdiction of the Bailiff, to the Secretary of the Gentlemen Aldermen of this municipality Joannes Mouris whereas all further sugar mills, arrack distilleries, chalk burners, brick and tile kilns, or lumber mills that are located outside of that, and lie or were set up in the countryside under the jurisdiction of the Sheriff ${ }^{29}$ to the Secretary of the District Council ${ }^{30}$ of these environs Samuel Hoorn, to report to the aforementioned respectively, the true number of such sugar mills, arrack distilleries, chalk burners, brick and tile kilns, or lumber mills, that he shall possess or receive in ownership, with addition of where these are located, and when they were set up, to then demonstrate these together, or bring them up to us in course of the aforementioned time, so as to then proceed with such decision over each of them, as we shall judge and decide to the best interest of our residents. On pain of that all such sugar mills[,] arrack distilleries, chalk burners[,] brick and tile kilns, so too lumber mills, that will be discovered and found out by the owner after expiration of aforementioned month beyond what had been declared, either shall the former be dismantled and confiscated, or these same will be subjected to such arbitral correction as would then be decided to accord after consideration of the case.

And as meanwhile the audacity and avarice of many people goes so far, that these take for aforementioned businesses and other usages, lands not yet given out by the Company, as their own, deprive [it of, or] take away the timber that stands there, wherefore these, being made bare of it, are made useless for the Hon. Company, the which would in the course of time thereby cause its inconvenience for the same, it is therefore decided with this to forbid each one whom it may be, so be it hereby forbidden, to chop or take no timber at any time, under whatever pretext it may be, from lands that still belong to the Hon. Company, and for which the possession of it has not been granted in a legal manner, on pain of a fine of two hundred Rixdollars or also other arbitral correction for the one who shall be caught or detected therein according to circumstance of persons and matters.

28. Suider voorstad, literally "southern suburb," is the present-day Glodok area of Jakarta (Balk et al. 2007: 68).

29. A Dutch landdrost (spelled lantdrost in the poster) was chief of a rural area larger than a village or estate, like an English early medieval reeve. But in present days, a reeve is head of a rural municipality in Canada. In South Africa, meanwhile, Afrikaans landdros $[t]$ corresponds to historical English sheriff, and this is the translation for the Dutch word used here following Balk et al. (2007: 68).

30. That is Heeren [College] van Heemraden translated here as "District Council" following Balk et al. (2007: 70). 
As however many people who may imagine or be of the opinion that if they have settled themselves on other lands of the Company or have managed and that one or more years have passed without their being prevented[,] such may be considered as a sufficient right of ownership [or] at least possession whereby they would nevertheless by greatly in error because nobody will be considered to have a legal right of ownership on any land other than when the transfer in case of a donation or letter of inheritance by this government can be presented that legal transmission before commissioned aldermen[,] if not of presumptive possession then granted by a legal decision of the District Council. And therefore as also to come out for once from the present obscurity and confusion as to the knowledge of the legality of the ownership of land estates that still belong to the Hon. Company so as to be able to draw a conclusion for the future, it is hereby confirmed and found fitting in the Council of India to decree, which is done herewith that everyone who believes to have the right of ownership or possession on some land the which through proper letters from us or our predecessors in this govt. cannot be shown to have been issued for the Company. Shall have to apply within the time of six months after the date and publication of this to the Secretary of the District Council of these countrysides Samuel Hoorn to let proper notation be made where such lands are located, when and on what grounds they have settled there or have taken possession of them[,] to then further await our orders and decision about it[,] and regardless of that somebody may have been granted or given some possession orally or in writing by the District Council or some members of the same[,] the which should then have been presented or declared at aforementioned notation on pain of that after expiration of the aforementioned time the claim of one who shall not have made such declaration and neglected having aforementioned notation made will not be believed and will be corrected according to circumstance.

And so that nobody may pretend any ignorance of the aforementioned we have found suitable that beyond the usual publication this admonition and announcement shall also be advertised in the Dutch, Chinese, Malay and Javanese language everywhere in places where such is appropriate and customary. Therefore do order, both Colleges of Justice, so too the District Council of these environs insofar it concerns their office, so too the respective public prosecutors namely the Advocate Prosecutor ${ }^{31}$ of India, the Bailiff and Sheriff, are each in their jurisdiction to appropriately attend to the carrying out of the aforementioned and have it attended to, as also to proceed against transgressors as is appropriate.

Issued in Fort Batavia on the Island Java Major this 24 July 1691:

By ordinance of Their Hon. High Com.:

W. van Outhoorn [...]

\section{C. van Swoll clerk}

31. Advocaet Fisc., modern advocaat-fiscaal "judge-advocate general," is rendered "advocateprosecutor" here, following Balk et al. (2007: 65). 